\title{
Plasma Cell Neoplasm
}

National Cancer Institute

\section{Source}

National Cancer Institute. Plasma Cell Neoplasm. NCI Thesaurus. Code C4665.

A clonal proliferation of immunog lobulin-secreting plasma cells. This category includes plasma cell myeloma, plasma cell leukemia, plasmacytoma, monoclonal immunoglobulin deposition disease, and monoclonal gammopathy of undetermined significance. 